\title{
Architectural Concepts and Safety Precaution Awareness on the Digitally Architecture Design Studio
}

\author{
Noor Cholis Idham \\ Department of Architecture \\ Universitas Islam Indonesia \\ Yogyakarta, Indonesia \\ noor.idham@uii.ac.id
}

\begin{abstract}
Building information technology has overtaken the way architect designing a building. The use of Building Information Modelling (BIM), somehow, sifted the designer viewpoint from general to detail- integrated aspects of the building. To indicate the system from detail preference will directly causing the wholeness of the building, including the integrity of the structural system and its configuration inside the building. On the other side, a studio culture in architecture study still follows the macro-micro path were design concepts start from extensive issues and involving intuition for creativity, which means somehow hardly touches the technicaldetailed aspects. The safety precaution of the structural system and its construction are then assumed strongly affected. To recognize either the use of digital tools has a link to the safety precaution, safety awareness is examined from the student's design on the architectural studios. Vertical and horizontal regularity, as well as the ease of egress, are the most factors chosen to represent how the design-work deals with the issues. The result shows that the level of the safety concept in the architectural studio needs more consideration. Some products found to neglect the matters since the architectural detail might be selected based on other precautions rather than safety issues. This discovery will might useful to reinforce more awareness of building safety in the school.
\end{abstract}

\section{Keywords: building safety, BIM, architectural design studio}

\section{INTRODUCTION}

Safety precaution is the most critical factor in every step of the building process, starting from the plan, designing, constructing, and occupying. Architectural design should take into consideration all aspects related to the design-works since its beginning from the initial concept. In a school of architecture, teachers should demand the students the safety issues as the first glance of the idea of the building design. However, the problems used to be related to the strength of the building exclusively involving the work of engineers. The probability of fragility even had started when the building did not plan yet. The future of the building masters beginning to acknowledge their profession. The architectural studio thus became one of the most influencing factors when the safety precaution should start.

In the architectural studios, when the student starts to investigate the building matters, the first essential issues are commonly related to the form and function of the buildings, then to building systems. Building integrity as a part of the system, unfortunately, is considered after most of the aspects of architectural design are readily done. The structural system is intended to be kept before meeting the structure consultants since the matters are related to the detailed design rather than an integrated system. This tendency would also happen in the professional field in the real project. Architects rarely discuss the safety precautions until they meet with the engineers.

The safety factors on the building design are related to the danger of the occupants from building collapse or fire on an earthquake; thus, building integrity and ease of evacuation are the most significant factors. Architectural concerns related to building integrity and escaping routes are not only dealing with the technical detail of building the structure but also the complete form of the building since the space-form is directly tied[1]. The plan shape, vertical continuity, and building structure and material are the most influencing aspects of integrity. Ease of access for escaping the danger also follows the direct and simplicity of the plan, the vertical passage of the building, and the evacuation systems [2].

Architectural studio nowadays starts to utilize the digital method, namely Building Information Modelling (BIM). On BIM, a building designer can initiate the safety precaution earlier since the integral aspect of the building is available. However, the design aspect of BIM is getting complicated by many systems come together on the studio process[3]-[6]. The design procedure could not be traditionally done through partial thinking creates such a 'disruptive' method in the design process. For professional work, this might be run without a severe problem, but in the case of the architecture, a student might be different. Since the students thinking on the integrated concept is relatively new, the general idea of the design might be not as rigid as a professional. The studio is a model of pedagogy where students can learn by each other from critique. Some scholars studied several issues in the studio, such as related to moral good, which is expected to be one of skill and knowledge development in the architectural studio [6]. The studio also means by collaborative and teamwork spirit [5]. As the design is complicated, to be creative needs involvement the various cognitive abilities. However, many intangible aspects of creativity could not instantly identify [3] as well as the intuition and practical elements [4].

Simple assessment from the earthquake vulnerability of a particular type of building has been published by FEMA 154. Quick evaluation is done as level-1 or tier-1, where the structural model is given by specific values following by subtraction from horizontal and vertical irregularity and soil 
condition[1]. Sarmah and Das applied in the simple reinforced concrete structure in India and found that the most vulnerable building is related to an overhang and adjacent buildings[7]. Idham also studied the level of earthquake threat with a similar procedure for Javanese houses and found that unconfined masonry is the most causing the liability[8]. The disaster vulnerability is also correlated to the ease of egress of the building. From many components linked with the escape route, the emergency stair is considered giving a significant role to save the occupants under the disaster evacuation. NFPA 101 Life Safety Code guides the path for evacuation where the fire stair should be arranged in a certain way to reach the open ground as soon as possible[2]. Huo et al. studied experimental evacuation on stair found a characteristic movement of the user from ninestory building [9]. Teknomo and Fernandez examine the time needed to escape as well as by Rendón Rozo et al. [10], [11].

This paper investigates how the students in the architectural studio deal with the issues. Some samples from the third year's works are examined to reveal the implementation of the safety aspect of the architectural concepts. To discover the vulnerability level from fire and earthquake disasters, we examined the earthquake vulnerabilities of the building design by the students by building integrity and ease access to evacuation. The building regularities both on horizontal and vertical directions are the main aspects, and the length of the route without hindrances that might emerge in the incident should be minimal. We evaluated the two elements on a detailed checking chart for the building irregularities and ease of evacuation route related to: (1) Plan simplicity, linked to a compact plan avoiding complicated building motion, (2) Section simplicity, associated with a simple accommodation to transfer the load without causing a torsion, (3) Emergency stairs proximity, associated to the stair existence and the length of the route, and (4) Evacuation egress, correlated to barrier-free access to escape. Every aspect here then is described according to the vulnerability level applied from one to four, where the least value is the excellent condition, and the greater value represents the high vulnerability (Table 1). Acceptable levels of the values are decided by more than 50 percent, which means the maximum level will be on level two.

TABLE I. THE EVALUATION COMPONENTS OF BUILDING VULNERABILITY AND ITS GIVEN VALUES

\begin{tabular}{|cccccc|}
\hline No. & $\begin{array}{c}\text { Plan } \\
\text { simplicity }\end{array}$ & $\begin{array}{c}\text { Section } \\
\text { simplicity }\end{array}$ & $\begin{array}{c}\text { Emergency } \\
\text { stairs }\end{array}$ & $\begin{array}{c}\text { Evacuation } \\
\text { egress }\end{array}$ & $\begin{array}{c}\text { Vulnerability } \\
\text { Values: }\end{array}$ \\
\hline 1 & $\begin{array}{c}\text { Compact } \\
\text { plan }\end{array}$ & $\begin{array}{c}\text { Simple- } \\
\text { continuous }\end{array}$ & $\begin{array}{c}\text { Max } 20 \mathrm{~m} \\
\text { available }\end{array}$ & $\begin{array}{c}\text { Direct to } \\
\text { open-air }\end{array}$ & 1 \\
\hline 2 & $\begin{array}{c}\text { Elongated } \\
\text { plan }\end{array}$ & $\begin{array}{c}\text { Complex- } \\
\text { continuous }\end{array}$ & $\begin{array}{c}\text { More than } \\
20 \mathrm{~m} \text { av. }\end{array}$ & Hidden stair & 2 \\
\hline 3 & $\begin{array}{c}\text { Symmetric- } \\
\text { wing plan }\end{array}$ & $\begin{array}{c}\text { Discontinuous } \\
\text { frame }\end{array}$ & $\begin{array}{c}\text { More than } \\
30 \mathrm{~m} \text { av. }\end{array}$ & $\begin{array}{c}\text { Unprotected } \\
\text { unventilated } \\
\text { stair }\end{array}$ & 3 \\
\hline 4 & $\begin{array}{c}\text { Asymmetric } \\
\text { plan }\end{array}$ & $\begin{array}{c}\text { Top-heavy } \\
\text { building }\end{array}$ & $\begin{array}{c}\text { Not } \\
\text { existence }\end{array}$ & $\begin{array}{c}\text { Dead-end } \\
\text { route }\end{array}$ & 4 \\
\hline
\end{tabular}

\section{FINDINGS AND DISCUSSION}

In the case of the 3rd-year architecture studio at the Department of Architecture of Universitas Islam Indonesia (UII), students have a public building design project. The theme of the 5th semester is a building with cultural representation where the main functions are for the cultural performance, museums, and a public meeting hall. While for the 6th semester, students have multi-story building design projects with the purpose of housing, hotel, hospital, and others. In these two semesters, safety against disaster is a significant request. Furthermore, the course statement of the course learning outcomes is also mentioning the safety aspect as one of the focus on the studios. From 100 samples of the $5^{\text {th }}$ and $6^{\text {th }}$ architectural studios, we discovered building vulnerability aspect as follows:

\subsection{Plan simplicity}

The simple plan determines the rigidity of the building, especially from swinging or twisting under earthquake. The compacted plan will firstly be expected as the stiffest followed by elongated, symmetric with wings, and asymmetric plan [1]. Plan with T, H, O shapes are symmetric while $\mathrm{L}$ form is asymmetric. Although they can achieve a good balance by configuring the number of columns and shear walls, the organization is still relatively vulnerable because of its irregularity [12].

It seems that architecture students do not widely follow simplicity in the plan. Most of the plans are even in asymmetric design, followed by symmetric, elongated, and compacted. Although the compact plan is the preferable plan to face the shear forces of an earthquake, its simplicity seems not to attract the student related to 'an aesthetic configuration' of the plan. For this reason, plan geometry is going in the opposite way, where the most popular shape is the most irregular (see figure 1).

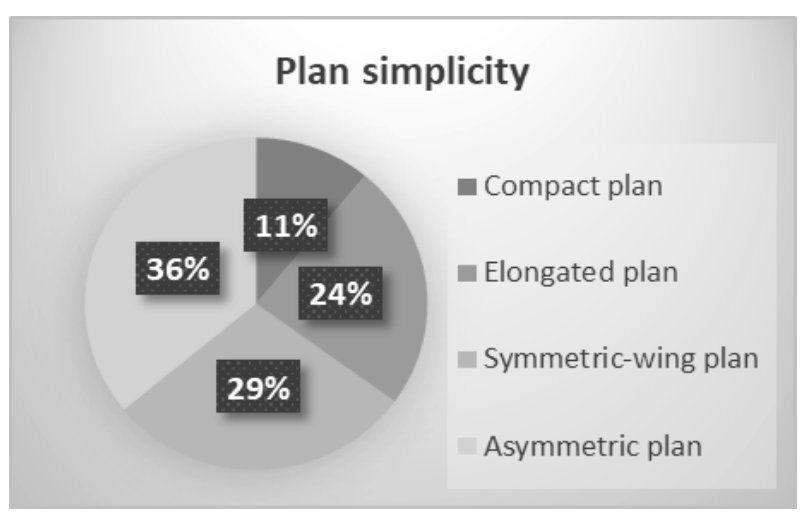

Fig. 1. Plan simplicity result where most of the design is in asymmetric as the weakest form of plan

\subsection{Section simplicity}

The building section represents the vertical regularity implied by the structural system elements such as columns and shear walls. The element arrangement will directly affect the gravitational load path and affects the balance. When an earthquake sways, the vertical irregularity will also impact the integrity of the buildings. Several building configurations, such as top-heavy, discontinue frame, and formal set-back is the most vertical irregularities [1]. The top-heavy structure is the weakest and should be avoided, followed by the discontinuous frame. A simple-continuous 
frame is most expected to be in the section with some complexity that is still acceptable.

The students somehow obey the vertical regularity. The top-heavy frame is a minority followed by the discontinuous structure. However, set back story as a complex-continuous form is easily found as a manifesto of the public floor on the first and second floor then continued by the typical level upper. The wide-span room located on the top floor is an option that implies the use of light structure, such as a truss or light frame. The complete figure can be seen in figure 2, where vertical irregularity is generally low.

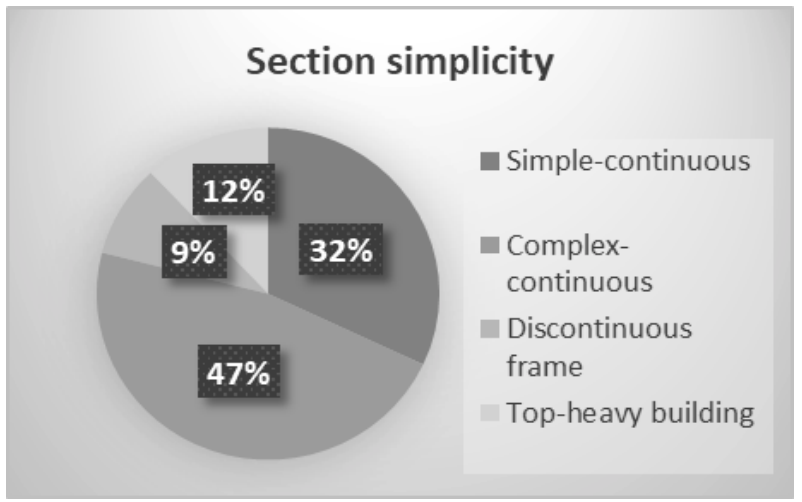

Fig. 2. Section or vertical irregularity is found minority

\subsection{Emergency stairs}

A stair is an essential element and the only support the safety in multi-story building egress [9]. The most considered aspect of the emergency stairs is its accessibility. The longest distance to the stair should not exceed 30 meters as the accepted level though some building class decreases down to 20 meters [13], [14]. Some adjustments are also available from 25 to 40 meters [15]. However, for this purpose, the limit of 30 meters is taken as its compatibility to the international standard. 20 -meter proximity is an ideal state followed by a maximum of 30 meters while exceeding distance is not accepted as more than level-2 vulnerability.

Unfortunately, the popularity of greater proximity than 30 meters to the stair is found dominating the population. The second majority of the sample found for an accepted level up to 30 meters. The rest are fallen in 20 meters as an ideal length to the stair while not existence is still observed as the students might depend only on non-fire stairs (figure 3 ). Emergency stair more than 30 meters away is commonly found in the wide-span public facilities where the stairs are in its sides or corners.

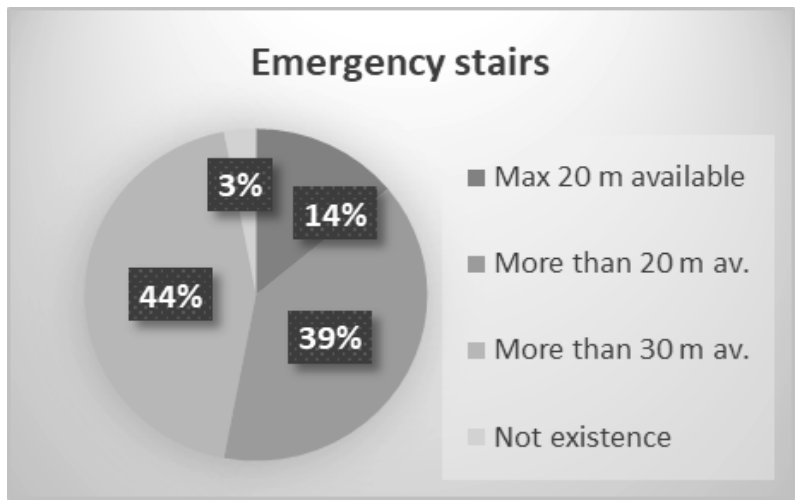

Fig. 3. The maximum proximity to the emergency stair is found more than 30 meters

\section{$1.4 \quad$ Evacuation egress}

Another aspect to be considered related to the evacuation is the ease of exit. An effective egress system is fundamental to user safety on the disaster[16]. The evacuation route should free from trapping the people on the way out, unprotected or unventilated shaft, and uneasy found stair. The general purpose of egress is to evacuate people out of the building as soon and safe as possible[2]. However, this egress also still considers the emergency stair as the crucial elements to the building safety. Direct to open landed stairs is expected to evacuate the occupants in the safest place. The hidden stair is also accepted as long as the signage or evacuation plan is available. The sign and plan will decrease the time needed to escape from danger [10]. Unprotected or unventilated stairs will become very dangerous when a fire spreads and touch the stair zone. Dead-end stair going to the basement is the real mortal trap of the building.

Dead-end stairs are unfortunately still can be found in the design as the stair not to lead to open-air directly while unprotected stairs enclosed in the building mass without protection or unventilated shaft is the most finding in this study. Hidden stairs, however, are also easily discovered as a result of a complicated building plan (figure 4). Students seem not to pay enough attention to the specific shaft of the stairs from fire and smoke as most of causing disaster when an earthquake may create a fire.

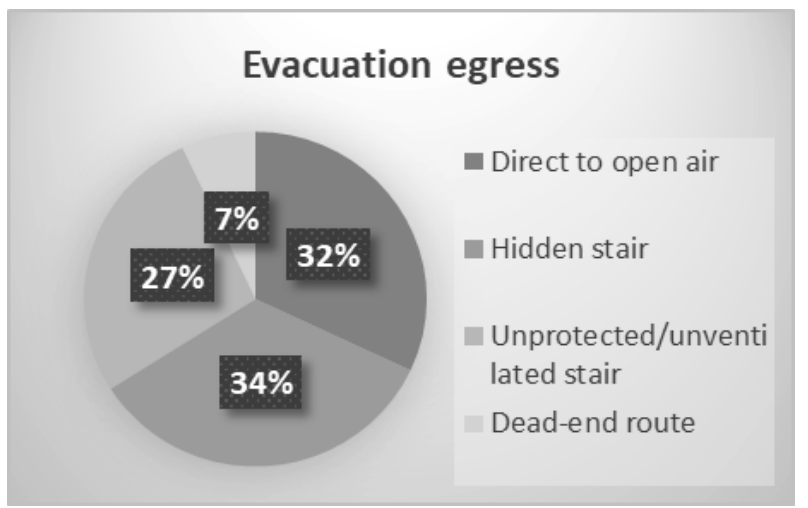

Fig. 4. Hilden stairways by mean of low visibility from the main halls still dominate the plan design

\subsection{Vulnerability level}

From the four aspects most causing the earthquake disaster, both for regularities and egress issues, the vulnerability unfortunately still exists. The emergency stair is the least performance related to its configuration. Irregularity of the plan is also widely discovered as 'a common mistake' of the architect's perspective of the aesthetic shape. From all evaluation, more than half of the samples are occupying level-1, and 2, which means almost all of them are safe enough. However, a large number of the design result still have level-3 and even level-4, where the buildings are in danger (figure 5). 
elements such as personal intuition and feeling involve each other in the studio work. The intuitive and practical context is always fill in both ways as distinctive characteristics of the studio. Integral thinking to the safety precaution should consider simplicity as the most significant design for safety. The perspective of building aesthetic should not lay on the complicated design. The notion of simplicity is beauty might be preferable.

\section{REFERENCES}

[1] FEMA 154, Rapid Visual Screening of Buildings for Potential Seismic Hazards. Redwood City: Applied Technology Council, 2002.

[2] NFPA, NFPA 101 Life Safety Code, 2015th ed. Quincy, Massachuset: NFPA, 2015.

[3] J. Y. Cho, "An investigation of design studio performance in relation to creativity, spatial ability, and visual cognitive style," Think. Ski. Creat., vol. 23, pp. 67-78, Mar. 2017.

Fig. 5. The level of a vulnerability is slightly under acceptance level

\section{CONCLUSIONS AND RECOMMENDATIONS}

Architecture studios work in the fifth and sixth semester in UII although most are accepted in safe level, however somehow still show an inaudibly high level of vulnerability from the earthquake disaster. The digital method of the works done after midterm schematic sketches in the rest halfsemester seems does not meet yet with the integral thinking for the fixed integrated BIM. Horizontal and vertical simplicity is hardly used in architecture design since the aesthetic values may not comply with the simplicities. Ease of egress, on another side, particularly related to the emergency stair, is still not profoundly considered yet.

Plan regularity, which also means simplicity, still somehow associated with the simple plan. It is generally assumed that the architect does not possess enough aesthetical capability. On the contrary, the complicated plan is often tied with the high aesthetical thinking of the architect. This perspective still followed in the architecture studio, the more complicated the design, the higher the appreciation given without considering others yet. It is the time that simplicity in architectural design does not always mean the poor quality of architecture look. In the sense of the vertical regularity, the simplicity is achieved more than the horizontal characteristics.

Design integration in BIM is practically done by employing and connecting the building components. However, the integrated concept behind is seemed oppositely with all aspects of the building. Too many intangible

[4] N. L. N. Ibrahim and N. Utaberta, "Learning in Architecture Design Studio,” Procedia - Soc. Behav. Sci., vol. 60, pp. 30-35, Oct. 2012.

[5] M. Emam, D. Taha, and Z. ElSayad, "Collaborative pedagogy in architectural design studio: A case study in applying collaborative design,” Alexandria Eng. J., vol. 58, no. 1, pp. 163-170, Mar. 2019.

[6] J. K. McDonald and E. Michela, "The design critique and the moral goods of studio pedagogy," Des. Stud., vol. 62, pp. 1-35, May 2019.

[7] T. Sarmah and S. Das, "Earthquake Vulnerability Assessment for RCC Buildings of Guwahati City using Rapid Visual Screening," in Procedia Engineering, 2018, vol. 212, pp. 214-221.

[8] N. C. Idham, "Seismic Vulnerability Assessment In Vernacular Houses: The Rapid Visual Screening Procedure for Non Engineered Building with Application to Java Indonesia,” Eastern Mediterranean University, 2011.

[9] F. Huo, W. Song, L. Chen, C. Liu, and K. M. Liew, "Experimental study on characteristics of pedestrian evacuation on stairs in a highrise building," Saf. Sci., vol. 86, pp. 165-173, Jul. 2016.

[10] K. Teknomo and P. Fernandez, "Simulating optimum egress time," Saf. Sci., vol. 50, no. 5, pp. 1228-1236, Jun. 2012.

[11] K. Rendón Rozo, J. Arellana, A. Santander-Mercado, and M. JubizDiaz, "Modelling building emergency evacuation plans considering the dynamic behaviour of pedestrians using agent-based simulation," Saf. Sci., vol. 113, pp. 276-284, Mar. 2019.

[12] N. C. Idham, Prinsip-Prinsip Desain Arsitektur Tahan Gempa, 1st ed. Yogyakarta: Penerbit Andi, 2014.

[13] SECURA, "Life Safety-Means of Egress/Exits-NFPA 101,” 2017.

[14] BCA, "BCA Design Compliance Report," Lachlan's Line Development Lot 104 (Buildings L \& M) Macquarie Park, Brookvale NSW, 2016.

[15] PERDA-DKI, Peraturan Daerah Daerah Khusus Ibukota Jakarta Nomor 7 Tahun 1991 Tentang Bangunan Dalam Wilayah Daerah Khusus Ibukota Jakarta. Indonesia, 1991.

[16] S. Grimaz and E. Tosolini, "Application of rapid method for checking egress system vulnerability,” Fire Saf. J., vol. 58, pp. 92-102, 2013. 